\title{
7. sinıf matematik dersinde zorlanılan konulara ilişkin öğrenci görüşlerinin incelenmesi
}

\author{
Okşan EVIRGEN ${ }^{1}$, Nazlı YILDIZ İKIKARDEŞ, ${ }^{2 * *}$ \\ ${ }^{1}$ Balıkesir Yakupköy Ortaokulu, Altteylül, Balıkesir. \\ ${ }^{2}$ Balıkesir Üniversitesi, Necatibey Eğitim Fakültesi, Matematik Eğitimi Anabilim Dall, Balıkesir \\ Geliş Tarihi (Recived Date): 24.09.2018 \\ Kabul Tarihi (Accepted Date): 06.12.2018
}

\section{Özet}

Bu çalışmanın amacı öğrencilerin 7.sınıf matematik öğretim programında (2005) zor olarak algıladikları konuları tespit etmek, bu konuların zor olarak algılamasinın nedenlerini ortaya koymak ve son olarak da bu konulardaki zorlukların giderilmesine yönelik çözüm önerileri sunmaktır. Araştırma nicel ve nitel yöntemlerin kullanıldı̆̆ iki bölümden oluşmaktadır. Çalışma 2013-2014 bahar yarıyılında Balıkesir Merkez'deki dört farklı ortaokulda öğrenim görmekte olan toplam 502 sekizinci sınıf öğrencisi ile gerçekleştirilmiştir. Öğrencilerin zor olarak algıladıkları 7. sınıf konularını belirlemek amacıyla "7.sınıf Matematik Dersi Konuları Zorluk Belirleme Anketi" 8.sinif öğrencilerine uygulanmıştır. Araştırmanın nicel verilerini desteklemek ve ögrencilerin konuları zor olarak algılamasının nedenlerini belirlemek amacıyla öğrencilerle yarı yapılandırılmış görüß̧meler yapılmıştır. Bu görüşmeler anketin uygulandı̆̆ı öğrenciler arasından rastgele seçilen 30 ögrenciye uygulanmıştır. Görüşmelerden elde edilen veriler içerik analizi yöntemi ile incelenmiştir. 2005 yedinci sınıf matematik öğretim programinda zor olarak algllanan konular belirlendikten sonra yenilenen 2013 yedinci sınıf matematik öğretim programı bu doğrultuda değerlendirilmiştir. Öğrencilerin bu konuları zor olarak algılamalarına ise konuların soyut olması, konu sayısının fazla olması, bazı konuların ögrenci seviyesinin üstünde olması, konuları pekiştirecek yeterli zamanın olmaması, ögrretmen faktörü, ön bilgi eksikliği ve derslerde kullanılan ögretim yöntemlerinin neden olduğu belirlenmiştir. Bu çalışmanın sonuçları literatürdeki benzer çalışmalarla karşılaştırılarak, zorlukların giderilmesine yönelik çözüm önerileri geliştirilmiştir.

Anahtar kelimeler: Yedinci sınıf matematik öğretim programı, zorluk indeksi, zor algılanan konular.

Okşan EVIRGEN, oksanaydin16@ @otmail.com, https://orcid.org/0000-0003-3653-3709

*Nazlı YILDIZ İIIKARDEŞ, nyildiz@balikesir.edu.tr, https://orcid.org/0000-0001-8756-8085 


\title{
Examination of the opinions of the students about the difficult topics in 7 th grade mathematics lesson
}

\begin{abstract}
The aim of this study is to identify topics perceived as difficult in seventh grade mathematics teaching program (2005), to put down the reasons why these topics are perceived as difficult and finally to present suggestions to overcome these difficulties. This study is composed of two parts in which quantitative and qualitative methods are used, respectively. The research was carried out in 2013-2014 spring semester, four different secondary school in province of Balikesir with 502 eighth grade students. "Seventh grade mathematics lesson topics difficulty identifying survey", which was prepared in order to determine the topics perceived as difficult, was applied to eighth grade students. Semi-structured interviews were conducted with students to support the quantitative data of the research and in order to determine the reasons why these topics are perceived as difficult by students. These interviews were conducted on randomly selected 30 students among the students to whom the questionnaire was applied. The data obtained from the interviews were analyzed using content analysis method. After determining the topics perceived as difficult in seventh grade mathematics teaching program (2005), the seventh grade mathematics teaching program (2013) is evaluated in this direction. The reason for this student perception was related to factors such as, be abstract of topics, having a greater number of topics, being some topics over the student's level, lack of sufficient time to consolidate topics, factor related to teacher, the lack of prior knowledge and teaching methods used in the lessons. Solution suggestions have been developed to overcome the difficulties by comparing the results of this study with similar studies in the literature.
\end{abstract}

Keywords: Seventh grade mathematics teaching program, difficulty index, topics perceived as difficult.

\section{Giriş}

Matematiğin insan hayatında büyük bir yer tutması sadece okullarda önem verilen bir ders olmasından kaynaklanmaz. Matematik okul dişında da insanların birçok sorununu çözmesine yardımcı olur. Bu nedenle matematiği sadece sayıları, işlemleri ve hesaplama becerilerini öğreten bir ders olarak görmemek gerekir. Matematik, giderek karmaşıklaşan yaşamda ayakta kalmamızı sağlayan düşünme, olaylar arasında ilişki kurma, akıl yürütme, tahmin yapma ve problem çözme gibi becerileri edinmemize yardımcı olur [1].

Dünyada bilginin önemi hızla artmakta, buna bağlı olarak bilgi kavramı ve bilim anlayışı da değişmekte, teknoloji ilerlemekte, demokrasi ve yönetim kavramları farklılaşmaktadır. Dolayısıyla tüm bu değişimlere ayak uydurabilmek için toplumların bireylerden beklediği beceriler de değişmektedir. Her alanda olduğu gibi eğitim alanında da değişim gerekmektedir [2]. 
Öğrenmenin nasıl gerçekleștiğini bilen öğretmen, öğrenme kuramlarına dayalı olarak geliştirilen öğretim modellerini, ilkelerini, yöntem ve tekniklerini daha kolay kavrar ve uygular. Öğrencilerin yaptıkları hataların kaynaklarını ve öğrenme güçlüklerinin nedenlerini açıklayabilir [3].

$\mathrm{Bu}$ güçlüklerin saptanması ve giderilmesi için eğitime yatırım yapan bir ülke, ülke kalkınmasına katkı sağlamak için eğitimi düzenlemek zorundadır. Bu düzenlemeler, eğitimin niteliği ile doğrudan ilişkili olan eğitim programları aracılığı ile gerçekleştirilir. Eğitim sisteminde ortaya çıkan problemlerin çözümü, bir ülkede izlenen Milli Eğitim politikasına ve eğitim programlarının geliştirilmesine bağlıdır. Çünkü nasıl bir insan yetiştirileceği sorusunun cevabı eğitim programları ile verilir [4].

Yeni matematik öğretim programı amaç, içerik, öğretim durumları ve değerlendirme boyutlarında birçok yenilikler içermektedir. Uygulanan programda bazı aksamalar ve eksiklikler görülebilir. Bu amaçla programın uygulanması sonucunda, yetersiz kalan ve ters işleyen öğelerin olup olmadığı; varsa aksaklıkların programın hangi öğelerinden kaynaklandığını tespit etmek ve gerekli düzeltmeleri yapmak amacıyla programın değerlendirilmesi gerekmektedir [5].

Birçok ülkede olduğu gibi Türkiye'de de matematik öğretimi ve öğreniminde bazı sorunların olduğu görülmektedir. Yapılan uluslararası düzeydeki çalışmalar Türkiye'nin matematik eğitiminde iyi bir konumda olmadığını göstermektedir. Örneğin, 38 ülkenin katıldığı uluslararası bir araştırmada Türk öğrencileri matematik başarısı sıralamasında ancak 31. sırayı alabilmişlerdir (The Third International Mathematics and Science Study [TIMSS], 1999). Diğer bir uluslararası araştırmada (Programme For International Student Assessment [PISA], 2003) ise Türk öğrencileri 41 ülke arasından 35. sirada ancak yer bulabilmişlerdir. Bu başarısızlık için birçok neden sayılabilir. Bunların başında öğretim ve öğrenmeye bakış açımız; bilginin, özellikle matematiksel bilginin doğası ve nasıl öğrenildiğinde anlamlı olduğu gelmektedir. Bu konuda yapacağımız küçük değişiklikler, öğrencilerin matematiksel kazanımları açısından büyük farklar yaratacaktır [6].

Ayrıca ülkemizde yapılan öğrenci seçme sınavlarında da matematik dersindeki başarının oldukça düşük olduğu görülmektedir. Bu durum öğrencilerin matematik öğretim programında yer alan konuları algılamakta sorun yaşandığını göstermektedir [7].

Bir konuda öğrencilerin karşılaştıkları güçlükleri bilmek, eğitim-öğretim sürecinin etkili olması ve bu konuda yapılacak çalışmalar bakımından önemli bir adımdır. Bu güçlükler yeni müfredatların yapılanmasına ve yeni öğretim stratejilerinin geliştirilmesine rehberlik etmektedirler. Ayrıca öğrencilerin öğrenme güçlüklerinin belirlenmesi, öğrenme sürecinde öğrenciye yardımcı olunması ve doğru rehberlik edilmesi içinde önemlidir. Özellikle matematikteki bir konuda öğrenme güçlüğü yaşayan bir öğrencinin, daha sonraki konularda başarılı olması zordur [8].

Matematik eğitiminin amac1, bütün öğrencilerin öğrenmeyi en üst düzeyde gerçekleştirmesidir. Fakat birkaçının bunu gerçekleştirmesine karşın, büyük çoğunluğun matematikte zorluk yaşaması yaşamın bir gerçeği olarak görülür [9]. Yaşanan bu zorlukların belirlenmesi ve giderilmesi, öğrenme sürecinde öğrenciye yardımcı 
olunması ve rehberlik edilmesi, çağdaş eğitimin gereklerinden olduğu kadar öğretmenin de görevleri arasında yer alır [10]. Bu nedenle öğretmenler, etkili bir şekilde anlamayı sağlayan öğrenme ortamlarını geliştirmek ve tasarlamak için matematik öğretmede öğrencilerin yaşamıș oldukları güçlüklerin farkında olmalıdırlar [11]. Bu doğrultuda, öğretmenlerin herhangi bir konuda öğrencilerin sahip oldukları güçlükleri bilmesi, öğrenme üzerine yapılan çalışmalar için önemli bir adımdır [12].

Bilim ve teknolojideki gelişmeler ile bireylerin, toplumun ve ekonominin ihtiyaçlarında değişmeler öğretim programlarının belirli aralıklarla güncellenmesini gerektirmektedir. Öğretim programlarının gözden geçirilmesi amacıyla 2005 yılında köklü bir değişime gidildi. Yapılan bu sadeleştirmeye rağmen öğretim programlarının gereğinden fazla yoğun olduğu düşünülmektedir. Bu yoğunluğa bağlı olarak programın felsefesinin uygulamaya yeterince yansımaması, etkinliklere yeterince zaman ayrilamamasının öğrencilerde öğrenme güçlüğüne neden olduğu belirtilmektedir. $\mathrm{Bu}$ nedenlerle 2013 yılında Milli Eğitim Bakanlığı ile TÜBİTAK arasında imzalanan protokol kapsamında ilköğretim ve ortaöğretimde bazı derslerin öğretim programları güncellendi [7] .

2012-2013 döneminde Türkiye'de 12 Ylllık Zorunlu Eğitim Sistemine (4+4+4) geçilmiştir. 4+4+4 Eğitim sistemi kendisinden önceki 5+3 Eğitim sisteminin aksine artık 4 sene ilkokul, 4 sene ortaokul ve 4 sene lise olmak üzere yeniden düzenlenmiştir. 2013 yılında Milli Eğitim Bakanlığı 5.sınıf matematik öğretim programını da ekleyerek ortaokul (5-6-7-8. sınıflar) matematik öğretim programını sadeleştirerek güncelledi [7].

Eğitim-öğretim sürecinin gelişimi; çıkmaz, eksik ve yanlışların giderilmesi, zorlukların aşılması ve sürekli bir yenilenme ile mümkün olmaktadır. Öğrencilerin zorluk çektikleri konuların belirlenmesi, bu konuda yapılacak çalışmalara temel oluşturmaktadır. Özellikle konularının birbirinin üzerine inşa edilmesi yönü ile yığılmalı bir bilim olarak nitelendirilen matematik dersinde, bir konuda öğrenme güçlüğü yaşayan bir bireyin ileriki öğrenmelerini sorunsuz gerçekleştirmesi mümkün olmamaktadır [13].

Literatürde zorluk çekilen konuların ve bunların olası nedenlerinin belirlenmesi hakkında pek çok araştırma yapılmıştır [9,14,15,16,17,18,19,20,21,22,23]. Bunların birçoğu ortaöğretim matematik konuları üzerine yapılmıştır. Durmuş ise bir önceki öğretim programında yer alan ilköğretim matematik konuları incelemiştir [23].

$\mathrm{Bu}$ çalışmada ise 7.sınıf matematik öğretim programında (2005) zor olarak algılanan konular ve bu zorlukların nedenleri araştırılmıştır. Bu çalışmadan elde edilen veriler sayesinde 7.sınıf matematik öğretim programının konu içeriği ve konuların öğrenilme sürecindeki eksikliklerin ortaya konulabileceği düşünülmektedir. Ayrıca bu çalışma 2005 matematik öğretim programında yer alan 7.sınıf matematik konularını içermesi ve yenilenen matematik programını değerlendirebilecek olması bakımından bu çalışmanın önemli olduğu düşünülmektedir.

Bu çalışmada, 7.sınıf matematik öğretim programında zor olarak algılanan konular ve bu zorlukların nedenleri belirlemek amaçlanmıştır. Bu amaca ulaşmak için aşağıdaki sorulara yanıt aranmıştır:

$\checkmark$ 7.sınıf matematik öğretim programında öğrenciler tarafından zor olarak algilanan konular nelerdir? 
$\checkmark$ Öğrenciler ile yapılan yarı yapılandırılmış görüşmelere göre zor algılamaların nedenleri nelerdir?

\section{Yöntem}

$\mathrm{Bu}$ çalışmada, nitel ve nicel araştırma yöntemleri bir arada kullanılmıştır [24]. Araştırmanın nicel boyutunda elde edilen verilere ulaşmak amacıyla tarama modeli kullanılmıştır [25]. Nicel verilere ulaşmak amacıyla öğrencilere 7.sınıf Matematik Dersi Konuları Zorluk Belirleme Anketi uygulanmış ve betimsel istatistikleri yapılarak zor olarak algılanan konular belirlenmeye çalışılmıştır. Araştırmanın nitel boyutunda ise durum çalışması modeli benimsenmiş, veriler öğrencilerle yapılan görüşmelerle elde edilmiştir [26]. Bu bölüm içinde çalışma grubu, veri toplama araçları, süreci ve veri analiz yöntemi açıklanmaktadır.

\section{1. Çalışma grubu}

Bu çalışmada, 2013-2014 öğretim yılında Balıkesir ili merkez ilçesinde bulunan 4 farklı ortaokul kurumlarında öğrenim görmekte olan 502 (253 K, 249 E) 8.sınıf öğrencisi ile çalışılmıştır. 502 öğrenci arasından rastgele seçilen 30 öğrenciye yarı yapılandırılmış öğrenci görüşme formu uygulanmıştır. Çalışmada özellikle 8.sınıf öğrencilerinin seçilmesindeki amaç, 7.sınıf öğretim programında yer alan konuları işlemiş bireyler olmalarıdır.

\subsection{Veri toplama araçlart}

7.sınıf Matematik Dersi Konuları Zorluk Belirleme Anketi, literatürde daha önce yapılmış olan çalışmalardan esinlenerek geliştirilmiştir. Bu çalışmada kullanılan anket Durmuş'un çalışmasında kullandığı ölçekten yararlanarak hazırlanmıştır [23]. Anket 7.sınıf Matematik Öğretim Programında (2005) yer alan kazanımlar doğrultusunda oluşturulmuştur. Anket hazırlanırken konu başlıkları belirlendikten sonra uzman görüşü de alınarak 35 konu başlığından oluşan bir anket elde edilmiştir. Anketteki soru maddelerine öğrencilerin verdiği yanıtların yüzdesi hesaplanarak her bir konunun zorluk indeksi belirlenmiştir. Bu anketteki zorluk indeksi Johnstone ve Mahmoud tarafından geliştirilmiş [27], Bahar, Johnstone ve Hansell, (1999) tarafından biyolojiye uyarlanmış ve Durmuş (2004b) tarafından matematiğe uyarlanarak kullanılmıştır. Ayrıca Johnstone ve Mahmoud (1980) tarafından geliştirilen zorluk indeksi hesaplama formülü Türkiye'deki bir çok araştırmada kullanılmıştır [8,17,20,21,22,23]. Durmuş [23] çalışmasında anket sonuçlarına dayalı olarak konuların zorluk indeksini belirlemiş ve zorluk indeksi "\% 15'in üzerinde olan konular öğrenciler tarafından zor olarak algılanmıştı"” varsayımına dayanarak araştırmasını yapmıştır. Bu çalışmada ise öğrencilere göre zorluk indeksi \%20'nin üzerinde olan konuların öğrencilerin en çok zorlandığı konular olduğu varsayılmıştır.

Zor olarak algılanan konular belirlendikten sonra, bu zorlukların nedenlerini belirlemek ve araştırmanın nitel verilerine ulaşmak amacı ile öğrencilerle yarı yapılandırılmış görüşmeler yapılmıştır. Görüşme soruları daha önce yapılmış olan çalışmalar taranarak oluşturulmuştur. Görüşme formunun anlaşılırlığının sağlanması için veri toplama sürecinden önce iki 8.sınıf ögrencisi ile görüşme test edilerek görüşme sorularına son hali verilmiştir. Görüşmelerde öğrencilerden izin alınarak ses kayıt cihazı kullanılmış, daha sonra bu ses kayıtlarından elde edilen veriler kelime kelime yazıya dökülmüştür. 


\subsection{Veri toplama süreci}

Araştırmada yer alan Zorluk Belirleme Anketi, Balıkesir il merkezinde yer alan dört farklı ortaokulda okuyan 502 8.sınıf öğrencilerine, gerekli izinler alındıktan sonra, okullara gidilerek uygulanmıştır. Anket uygulanırken, her sınıfta anket tanıtılarak ve nasıl cevaplanacağı ile ilgili yönerge okunarak yapılmıştır. Katılımcılara anketleri doldurmaları için 15-20 dakika süre tanınmıştır.

\subsection{Verilerin analizi}

Öğrenciler konuların zorlukları ile ilgili düşüncelerini "kolaydı", "biraz zor", "zordu" ve "hiç görmedim" şeklinde ifade etmişlerdir. Araştırmada elde edilen bu nicel veriler Excel programı yardımıyla işlenerek ve zorluk belirleme formülü kullanılarak her bir konuya ait daha önce bahsedilen zorluk indeksleri hesaplanıp, betimsel istatistik kullanılarak analiz edilmiştir.

Görüşme formu kullanılarak öğrencilerle yüz yüze yapılan görüşmeler sonucunda elde edilen görüşme kayıtları, hiç bir değişiklik yapılmadan olduğu gibi yazılmıştır. Görüşmelerden elde edilen veriler, içerik analizi yapılarak çözümlenmiştir. İçerik analizinde veriler, betimsel analize göre, daha derin bir işleme tabi tutulur. Betimsel analizde gözden kaçan kavram ve temalar içerik analizi sonucu keşfedilebilir [26]. Görüşmeler sonucunda, yazıya dökülen veriler, üzerinde kodlamalar yapılarak metin üzerinde işaretlenmiştir. Birbiri ile ilişkili olan kodlar bir araya getirilerek ortak temalar altında toplanmıştır. Görüşme formunun uygulandığ öğrencilere numaralar verilmiş ve alıntılar bu numaralar kullanılarak yapılmıștır.

\section{Bulgular}

$\mathrm{Bu}$ kısımda araştırmanın verilerinin analizinden elde edilen bulgular, araştırmanın sorularına göre sunulmakta ve yorumlanmaktadır.

\subsection{Birinci soruya ilişkin bulgular ve yorum}

Araştırmanın "7.sınıf matematik öğretim programında öğrenciler tarafından zor olarak algılanan konular nelerdir?” sorusuna yönelik öğrencilerin verdikleri yanıtların dağılımı ve her konu için öğrenme zorluğu indeksi hesaplanarak Tablo 1'de verilmiştir. A: "Bu konu benim için kolaydı" diyen öğrenci sayısını, B: "Biraz zor bir konuydu ama sonunda anladım" diyen öğrenci sayısını, C: "Bu konu benim için zordu" diyen öğrenci sayısını, D: "Bu konuyu hiç görmedim” diyen öğrenci sayısını temsil etmektedir.

Tablo 1. Öğrencilerin zor olarak algıladıkları konulara ait zorluk indeksleri.

\begin{tabular}{|c|l|l|c|l|c|c|c|}
\hline NO & KONULAR & ÖĞRENME ALANI & A & B & C & D & $\begin{array}{c}\text { ZORLUK } \\
\text { INDEKSİ }\end{array}$ \\
\hline $\mathbf{1}$ & Faiz hesaplamaları & Sayılar & 149 & 202 & 140 & 11 & 28,51 \\
\hline $\mathbf{2}$ & Denklem problemleri & Cebir & 176 & 197 & 116 & 13 & 23,72 \\
\hline $\mathbf{3}$ & Denklemler & Cebir & 219 & 174 & 102 & 7 & 20,60 \\
\hline $\mathbf{4}$ & $\begin{array}{l}\text { Dik dairesel silindirin } \\
\text { hacmi }\end{array}$ & Ölçme & 146 & 226 & 95 & 35 & 20,34 \\
\hline $\mathbf{5}$ & Yüzde hesaplamaları & Sayılar & 235 & 169 & 91 & 7 & 18,38 \\
\hline
\end{tabular}


Tablo 2. (Devami).

\begin{tabular}{|c|c|c|c|c|c|c|c|}
\hline 6 & $\begin{array}{l}\text { Dik dairesel silindirin } \\
\text { alanı }\end{array}$ & Ölçme & 154 & 233 & 84 & 31 & 17,83 \\
\hline 7 & $\begin{array}{l}\text { Rasyonel sayılarla çok } \\
\text { adımlı işlemler }\end{array}$ & Say1lar & 208 & & 83 & 5 & 16,70 \\
\hline 8 & Permütasyon & Olasılık ve istatistik & 225 & & 79 & 25 & 16,56 \\
\hline 9 & Cebirsel ifadeler & Cebir & 238 & & 77 & 7 & 15,55 \\
\hline 10 & $\begin{array}{l}\text { Rasyonel sayılarla ilgili } \\
\text { problemler }\end{array}$ & Sayılar & 205 & & 72 & 7 & 14,54 \\
\hline 11 & $\begin{array}{l}\text { Çember veya dairede } \\
\text { açılar }\end{array}$ & Geometri & 251 & & 70 & 8 & 14,17 \\
\hline 12 & $\begin{array}{l}\text { Doğrusal denklemlerin } \\
\text { grafikleri }\end{array}$ & Cebir & 263 & & 67 & 21 & 13,92 \\
\hline 13 & $\begin{array}{l}\text { Birim küplerle oluşturulan } \\
\text { yappları izometrik kağıda } \\
\text { çizme (sağdan, soldan } \\
\text { üsten ve alttan görünüm) }\end{array}$ & Geometri & 300 & & 66 & 26 & 13,86 \\
\hline 14 & $\begin{array}{l}\text { Dairenin ve daire } \\
\text { diliminin alanı }\end{array}$ & Ölçme & 200 & & 67 & 11 & 13,64 \\
\hline 15 & $\begin{array}{l}\text { Çemberin ve çember } \\
\text { parçasının uzunluğu }\end{array}$ & Ölçme & 225 & & 58 & 13 & 11,86 \\
\hline 16 & Oran ve orant 1 & Sayılar & 301 & & 55 & 5 & 11,06 \\
\hline 17 & $\begin{array}{l}\text { Rasyonel sayılarla } \\
\text { işlemler }\end{array}$ & Sayılar & 298 & & 54 & 4 & 10,84 \\
\hline 18 & Koordinat sistemi & Cebir & 327 & & 53 & 5 & 10,66 \\
\hline 19 & $\begin{array}{l}\text { Rasyonel sayıları } \\
\text { karşılaştırma ve sıralama }\end{array}$ & Sayılar & 339 & & 44 & 2 & 8,80 \\
\hline 20 & $\begin{array}{l}\text { Rasyonel sayıların farklı } \\
\text { gösterimi }\end{array}$ & Sayılar & 282 & & 43 & 1 & 8,58 \\
\hline 21 & $\begin{array}{l}\text { Dörtgensel bölgelerin } \\
\text { alanları }\end{array}$ & Ölçme & 287 & 167 & 42 & 6 & 8,46 \\
\hline 22 & Eşlik ve benzerlik & Geometri & 316 & 134 & 41 & 11 & 8,35 \\
\hline 24 & $\begin{array}{l}\text { Çokgenlerin iç açılarının } \\
\text { ölçüleri }\end{array}$ & Ölçme & 314 & 149 & 38 & 1 & 7,58 \\
\hline 25 & $\begin{array}{l}\text { Merkezi eğilim ve } \\
\text { yayılım ölçüleri }\end{array}$ & İstatistik ve olasılık & 345 & 111 & 35 & 11 & 7,12 \\
\hline 26 & $\begin{array}{l}\text { Rasyonel sayıları sayı } \\
\text { doğrusunda gösterme }\end{array}$ & Sayılar & 345 & 120 & 35 & 2 & 7,00 \\
\hline 27 & Çokgenler & Geometri & 360 & 107 & 35 & 0 & 6,97 \\
\hline 28 & Tam sayılarla işlemler & Sayılar & 393 & 77 & 31 & 1 & 6,18 \\
\hline 29 & $\begin{array}{l}\text { Tam sayılarla ilgili } \\
\text { problemler }\end{array}$ & Sayılar & 324 & 142 & 30 & 6 & 6,04 \\
\hline 30 & Dönme & Geometri & 382 & 83 & 27 & 10 & 5,48 \\
\hline 31 & Doğrular ve açılar & Geometri & 357 & 114 & 26 & 5 & 5,23 \\
\hline
\end{tabular}


Tablo 3. (Devami).

\begin{tabular}{|l|l|l|l|l|l|l|c|}
\hline $\mathbf{3 2}$ & $\begin{array}{l}\text { Süsleme ve süslemedeki } \\
\text { kodları belirleme }\end{array}$ & Geometri & 392 & 89 & 17 & 4 & 3,41 \\
\hline $\mathbf{3 3}$ & Örüntüler ve ilişkiler & Cebir & 425 & 58 & 16 & 3 & 3,20 \\
\hline $\mathbf{3 4}$ & Yansıma & Geometri & 444 & 42 & 15 & 1 & 2,99 \\
\hline $\mathbf{3 5}$ & Tablo ve grafikler & Olasılık ve istatistik & 443 & 48 & 10 & 1 & 1,99 \\
\hline
\end{tabular}

Tablo 1'de verildiği gibi "faiz hesaplamaları", "denklem problemleri”, "denklemler", "dik dairesel silindirin hacmi" konularının zorluk indeksleri \%20'nin üzerinde olduğu belirlenmiștir. Bunun yanı sıra "süsleme ve süslemedeki kodları belirleme", "örüntüler ve ilişkiler", "yansıma", "tablo ve grafikler" konularının zorluk indekslerinin \%5'in altında ve oldukça düşük olduğu ortaya çıkmıştır. Bu öğrenciler için özellikle "tablo ve grafikler" konusu "bu konu benim için kolaydı" seçeneğini işaretleyen öğrenci sayısına bakılırsa öğrenilmesi en kolay konu olarak ortaya çıkmaktadır.

\subsection{Ikinci soruya ilişkin bulgular ve yorum}

7.sınıf matematik öğretim programında öğrencilerin zor olarak algıladıkları konuların arkasında yatan nedenleri belirlemek amacıyla, öğrencilerin bu nedenleri kendi cümleleri ile ifade etmelerinin sağlanması için yapılan görüşmeler, öğrencilerden izin alınarak ses kayıt cihazı ile kaydedilmiş, daha sonra kelime kelime yazılmıştır.

\subsection{1. Ö̆grencilerle yapılan görüsşmelerden elde edilen bulgular}

Öğrencilerin matematik dersini zor bir ders olarak görmeleri ile ilgili bilgi elde etmek amacı ile öğrencilere "Öğrenciler genel olarak matematik dersini zor bir ders olarak görürler. Sence matematik dersi neden öğrencilere zor geliyor?” sorusu yöneltilmiştir. Öğrencilerin bu soruya verdikleri yanıtlar Tablo 2' de görülmektedir.

Tablo 2. Öğrenci görüşme formu birinci soru kategori tablosu.

\begin{tabular}{|c|c|}
\hline & İfade eden öğrenciler \\
\hline \multicolumn{2}{|l|}{ Duyuşsal nedenler } \\
\hline Ders öğretmeninin sevilmemesi & Ö2,Ö17 \\
\hline Konuların zor hissedilmesi & Ö2,Ö12,Ö13,Ö14,Ö17,Ö20 \\
\hline İşlemlerin karışık hissedilmesi & Ö3,Ö4,Ö5,Ö20,Ö21,Ö25,Ö27,Ö29 \\
\hline Dersten nefret edilmesi & Ö23 \\
\hline Ders ile ilgili aile baskısı & Ö19 \\
\hline \multicolumn{2}{|l|}{ Matematik dersinin içeriği } \\
\hline İşleme bağlı bir ders olması & Ö3,Ö8,Ö9,Ö13,Ö15 \\
\hline Konuların çok olması & Ö3,Ö5,Ö20 \\
\hline Sayısal bir ders olması & Ö7,Ö9,Ö11,Ö16,Ö28 \\
\hline Çok farklı soru tiplerinin olması & Ö13,Ö14, \\
\hline Konuların birbiri ile ilişkili olması & Ö23 \\
\hline $\begin{array}{l}\text { Ezber yönteminin ve sadece okumanın başarı için yeterli } \\
\text { olmaması }\end{array}$ & Ö3,Ö8,Ö11,Ö27 \\
\hline Çok formül ezberleme ihtiyacı ve zorluğu & Ö9,Ö13,Ö21 \\
\hline Mantık yürütmenin gerekliliği & Ö3,Ö11,Ö13 \\
\hline İşlemlerin vakit alıcı olması & Ö9,Ö26 \\
\hline Konuların pekiştirilmesinde zaman sıkıntısı yaşanması & Ö14 \\
\hline
\end{tabular}


Tablo 2. (Devami).

\begin{tabular}{|c|c|}
\hline \multicolumn{2}{|l|}{ Matematik korkusu } \\
\hline Baştan başaramayacağı düşüncesi & Ö6,Ö7,Ö10,Ö18, Ö19 \\
\hline Bazı öğretmenlerin sınavlarda zor soru hazırlayacağı düşüncesi & Ö10 \\
\hline Bazı soru çeşitlerinin, seviyesinin üstünde olduğu düşüncesi & Ö15 \\
\hline Sadece zeki öğrencilerin dersten başarılı olabileceği düşüncesi & Ö13 \\
\hline \multicolumn{2}{|l|}{ Öğrenciden kaynaklanan nedenler } \\
\hline Tekrar yapılmaması & Ö1,Ö26,Ö30 \\
\hline Yeterli çalışımaması & Ö2, Ö6, Ö30 \\
\hline Çok soru çözülmemesi & Ö8 \\
\hline Çalışmaya karşı isteksiz olması & Ö22,Ö25,Ö27,Ö19 \\
\hline Soruları çözememesi & Ö24 \\
\hline
\end{tabular}

Görüşmeye katılan öğrencilerin birinci soruya ilişkin verdiği yanıtlar Duyuşsal nedenler, Matematik dersinin içeriği, Matematik korkusu ve Öğrenciden kaynaklanan nedenler olmak üzere 4 tema altında toplanmıştır. Buna göre duyuşsal nedenler temasına ilişkin olarak öğrenciler işlemlerin karışık hissedilmesi, konuların zor gelmesi, ders öğretmeninin sevilmemesi, dersten nefret edilmesi ve ders ile ilgili aile baskısı gibi nedenlerle matematik dersinin zor bir ders olarak görüldügüunü belirtmiştir. Öğrencilerin bu yöndeki ifadelerine ilişkin örnekler aşağıda verilmiştir.

"Bence problemleri çözmek zor geliyor. Bazen de öğretmenlerin etkisi oluyor. Ögretmenler ögrenciye kötü davranırsa zor gelebilir ögrenciye. Öğrenci anlamak istemez. Bu seneki ögretmenimiz bize çok iyi davrantyor. Bende matematiği sevmeye başladım (Ö17)”.

"Bir kere gözümüzde büyütüyoruz matematik dersini. Bir de bazı konular gerçekten zor. Çalışmakta zor geliyor. Ailelerden geliyor. Matematiği iyi dinle, o ders zordur, o ders çok önemli diyor, çocuğun gözünde büyütülüyor. Matematikte püf noktayı bulursan kolaylaşıyor (Ö19)".

Matematik dersinin içeriği temasına ilişkin olarak öğrenciler, matematik dersinin işleme bağlı bir ders olması, sayısal bir ders olması, konu sayısının çok fazla olması, konuların birbiri ile ilişkili olması ve çok farklı soru tiplerinin olması nedeniyle matematik dersinin zor bir ders olarak görüldüğünü ifade etmişlerdir. Öğrencilerin bu yöndeki ifadelerine ilişkin örnekler aşağıda verilmiştir.

"Çünkü daha çok işlemlerden oluşuyor. Geometri konuları daha çok zorluyor. Diğer konuları çalışarak öğreniyoruz ama geometride mantı̆̆ımızı kullanmamı gerekiyor. Bazı şekillerde çok değişik soru tipi gelebiliyor. Geometride bazı kurallar var o kuralları ezberlemek zor. Bazı şekillerde çok fazla değişik soru tipi gelebiliyor. Denklemler zorluyor denklemleri anlamak için zeki bir öğrenci olmak gerekiyor (Ö13)”.

"Çünkü sınıf artıkça konular daha çok artmaya başlıyor. Birikiyor, karışmaya başlıyor. Bir anlık ufak kaydırmada birçok konuyu kaçırlyorsun. Denklemlerde iyi olmazsan, denklemle ilgili bütün soruları kaçırıyorsun. Bir yerlerde kaçırırlarsa, anlamıyorlar nefret ediyorlar. (Ö23)".

Öğrenciler matematik dersinin içeriği ile ilgili olarak ezber yönteminin ve okumanın matematik dersinde başarılı olmak için yeterli olmaması, matematik dersinde mantık kullanmanın ve çok fazla formül ezberlemenin gerekli olması, işlemlerin vakit alıcı 
olması, konuların pekiştirilmesinde zaman sıkıntısı olduğu için matematik dersinin zor bir ders olarak görüldüğünü ifade etmiştir.

"Daha karışık geliyor böyle işlemler çok toplama, çıkarma, çarpma var. Bence karışık geldiği için beyinlerini daha çok yoruyorlar. Türkçe de ezberliyorlar ama matematikte daha çok mantıklarını kullanmaya çalışıyorlar buda zorluyor. Türkçe' yi ele alalım ezberleyince tüm Türkçe sorularını çözebiliyorlar. Çok fazla konu var (Ö3)”.

"Bence zor değil ama böyle sayılarla çok fazla işlem buluyoruz. Önden bir şey bulup sonra bir daha bir daha üstüne ekleniyor falan ya. Çok şey öğreniyoruz, formüller ezberliyoruz, bence ondan zor geliyor. Bence işlemler yüzünden sevilmiyor. Çok vakit kaybı oluyor çok zaman gerekiyor (Ö9)”.

Matematik korkusu teması ile ilgili olarak, baştan başaramayacağı, bazı öğretmenlerin sınavlarda zor soru hazırlayacağı, bazı soru çeşitlerinin seviyesinin üstünde olduğu, sadece zeki öğrencilerin bu dersten başarılı olabileceği düşünceleri ile matematik dersinin zor bir ders olarak görüldüğünü ifade etmiştir. Öğrencilerin bu yöndeki ifadelerine ilişkin örnekler aşağıda verilmiştir.

"Yapamadıklar için zor geliyor. Yeteri derecede üzerinde durmuyoruz. Baştan yapamayacağımızı düşünüyoruz (Ö6) ”

"Matematikte bir ön yargı oluşmuş diye düşünüyorum. Bazı öğretmenlerinin sorularının zor olduğunu düşünüyorlar. $O$ yüzden ön yargıyla yaklaştıklarını düşünüyorum.(Ö10)”.

Öğrenci kaynaklı nedenlerle teması ile ilgili olarak; öğrenciler, çalışmaya karşı isteksiz olunması, tekrar yapılmaması ve yeterli çalışılmaması, çok soru çözülmemesi ve öğrencilerin soruları çözememesi gibi nedenlerle matematik dersinin zor bir ders olarak görüldüğünü ifade etmiştir.

"Bana zor gelmiyor. Genelde çalışma isteyen bir ders tekrar yapmadıkları için sorun yaşıyorlar (Ö1)”.

Görüşme formunun ikinci ve dördüncü sorusu " 7 .sınıf matematik konularını ele alırsak, hangi konularda daha çok zorlanıyordunuz?" ve " 7. sınıf matematik konularından hangileri olmasaydı matematik dersindeki başarın daha yüksek olurdu?" şeklindedir. Bu sorular ortak analiz edilmiştir ve kategori tablosu aşağıda verilmiştir.

Tablo 3. Öğrenci görüşme formu ikinci ve dördüncü soru kategori tablosu.

\begin{tabular}{ll}
\hline Zor Olarak Algılanan Konular & İade eden öğrenciler \\
\hline Faiz hesaplamaları & Ö1,Ö2,Ö5,Ö6,Ö9,Ö14,Ö15,Ö19,Ö20,Ö21,Ö22,Ö23,Ö25,Ö29 \\
Yüzde hesaplamaları & Ö1,Ö2,Ö5,Ö6,Ö9,Ö14,Ö15,Ö19,Ö20,Ö21,Ö24,Ö26,Ö28,Ö30 \\
Permütasyon & Ö1,Ö2,Ö4,Ö7,Ö8,Ö18,Ö21,Ö23,Ö26,Ö27,Ö28, \\
Denklemler & Ö2,Ö5,Ö8,Ö12,Ö13,Ö17,Ö20,Ö26,Ö27,Ö28 \\
Dik dairesel silindirin hacmi & Ö5,Ö7,Ö9,Ö11,Ö14,Ö19,Ö20,Ö21,Ö27 \\
Cebirsel ifadeler & Ö4,Ö6,Ö16,Ö17,Ö20,Ö21,Ö26,Ö27 \\
Dik dairesel silindirin alanı & Ö5,Ö7,Ö11,Ö14,Ö19,Ö21,Ö27 \\
Oran ve orantı & Ö6,Ö9,Ö6,Ö17,Ö18,Ö20,Ö30 \\
Doğrusal denklemlerin Grafikleri & Ö4,Ö6,Ö9,Ö13,Ö15 \\
Koordinat sistemi & Ö6,Ö11,Ö15,Ö17 \\
Çember veya dairede açılar & Ö10,Ö14,Ö16,Ö27 \\
\hline
\end{tabular}


Tablo 3. (Devami).

$\begin{array}{ll}\text { Çokgenler } & \text { Ö4,Ö16,Ö12,Ö30 } \\ \text { Denklem problemleri } & \text { Ö5,Ö12,Ö21 } \\ \text { Merkezi eğilim ve yayılım ölçüleri } & \text { Ö4,Ö26,Ö27 } \\ \begin{array}{l}\text { Birim küplerle oluşturulan yapıları } \\ \text { izometrik kağıda çizme }\end{array} & \text { Ö4,Ö7,Ö14, } \\ \text { Eşlik ve benzerlik } & \text { Ö2,Ö11,Ö23 } \\ \text { Rasyonel sayılarla ilgili problemler } & \text { Ö20,Ö27 } \\ \text { Dairenin ve daire diliminin alanı } & \text { Ö11,Ö14 } \\ \text { Tablo ve grafikler } & \text { Ö2,Ö15 } \\ \text { Dörtgensel bölgelerin alanları } & \text { Ö14,Ö19 } \\ \text { Süsleme ve süslemedeki kodları } & \text { Ö3,Ö26 } \\ \text { belirleme } & \text { Ö16,Ö17 } \\ \text { Tam sayılarla işlemler } & \text { Ö17 } \\ \text { Tam sayılarla ilgili problemler } & \text { Ö3 } \\ \text { Rasyonel sayılarla çok adımlı şlemler } & \text { Ö23 } \\ \text { Doğrular ve açılar } & \text { Ö9 } \\ \text { Örüntüler ve ilişkiler } & \end{array}$

Öğrencilerden 14 tanesi zorlandıkları konuların "Faiz hesaplamaları" ve "Yüzde hesaplamaları" olduklarını belirtmişlerdir. Dolayısıyla en çok zorlanılan konular "Yüzde ve Faiz hesaplamaları" dır. Öğrenciler sirasıyla "Permütasyon", "Denklemler", "Dik Dairesel Silindirin Hacmi", "Cebirsel İfadeler", "Dik Dairesel Silindirin Alanı", "Oran ve orantı" ve "Doğrusal Denklemlerin Grafikleri" konularında daha çok zorlandıklarını belirtmiştir. Öğrencilerin bu yöndeki ifadelerine ilişkin örnekler aşağıda verilmiştir.

"Yüzde hesaplamaları ve faiz hesaplamaları, çember ve daire de açılar, birim küplerle oluşturulan yapıların izometrik kâğıda çizimi, daire diliminin alanı, silindirin alanı ve hacmi. Biraz da okulun sonuna doğru olduğu için kendimi saldım. Çok çalışmadım ve anlamadım. Faiz hesaplarında okulda yüzde kurarak dershanede formülle çözüyordum. Ben denkleştiremedim. O yüzden olmadı (Ö14)”.

"Cebirsel ifadeler, faiz hesapları, permütasyonu da başta anlayamamıştım. Bide silindirin alanı ve hacmi son dönemde işlemiştik, çok iyi anlayamamıştım. Denklem problemleri, problemin denklemini kuramıyorum kurulsa çözüyordum. Silindirin hacmi ve alanı, faiz ve yüzde hesaplamaları (Ö21)".

Öğrencilerden 3 tanesi geometri konularında zorlandıklarını özellikle belirtmiştir. Bir öğrenci ise özellikle geometri konularının daha kolay olduğunu ifade etmiştir.

"Süslemede kodları belirleme, rasyonel sayılarda çok adımlı işlemler karışık geliyordu. Ben geometri konularında daha çok zorlandım. Geometride daha çok kural oluyor. Ögrenciler daha çok zorlanıyorlar (Ö3)”.

"Geometri konularını genelde çok sevmem. Matematiği daha çok severim. Dik dairesel silindirin alanı ve hacmi ile dairenin alanında zorlandım (Ö11)”.

Öğrencilerin eğitim-öğretim sürecine ilişkin görüşlerini belirlemek amaciyla öğrencilere görüşme formunun üçüncü sorusu olan "Öğretmeniniz matematik dersini nasıl işlerdi? Bu ders işleme şeklinden memnun muydun? Neden?" sorusu yöneltilmişstir. 
Tablo 4. Öğrenci görüşme formu üçüncü soru kategori tablosu.

SORU 3: "Öğretmeniniz matematik dersini nasıl işlerdi? Bu ders işleme şeklinden memnun muydun? Neden?"

\begin{tabular}{ll} 
& ifade eden öğrenciler \\
\hline Memnuniyet & \\
\hline Öğretmenin kişisel özellikleri & \\
\hline Esprili olması & Ö3,Ö25,Ö22 \\
Neşeli olması & Ö3,Ö27 \\
Çok sert olmaması & Ö3 \\
Disiplinli olması & Ö13 \\
\hline Öğretmenin eğitim- öğretim sürecine pozitif etkisi & \\
\hline Dersin eğlenceli geçmesi & Ö1,Ö2,Ö3,Ö4,Ö9,Ö22, \\
Çok soru tipi ile karşışsıııması & Ö12,Ö13,Ö23 \\
Konunun pekiştirilmesi & Ö5,Ö15,Ö30 \\
Öğrencinin Ödüllendirilmesi & Ö9,Ö25,Ö27 \\
Anlaşılmadığında yeniden anlatılması & Ö21,Ö26,Ö22 \\
Öğrencinin aktif olması & Ö24,Ö27 \\
Dersin soru üzerinden anlatılması & Ö11,Ö12 \\
Öğrencinin seviyesine inilebilmesi & Ö1 \\
Dersin hızlı işlenmemesi & Ö9 \\
Öğrencinin yapamadığı soruyu öğretmene sorabilmesi & Ö14 \\
Öğretmenin sevilmesi & Ö1
\end{tabular}

\begin{tabular}{ll}
\hline Memnuniyetsizlik & \\
\hline Öğretmenin eğitim- öğretim sürecine negatif etkisi & \\
\hline Konuların üzerinde çok durulmaması & Ö6,Ö7 \\
Dersin sıkıcı geçmesi & Ö18,Ö29 \\
Dersin çok hızlı işlenmesi & Ö19 \\
Belirli sayıda öğrenciyle dersin işlenmesi & Ö18 \\
Öğretmenin öğrencileri susturamaması & Ö20 \\
Öğrenci yapamazsa öğretmenin kızması & Ö17 \\
Dersin kitaptan işlenmemesi & Ö28 \\
Derste çok zor soru çözülmemesi & Ö16 \\
\hline
\end{tabular}

Görüşmeye katılan öğrencilerin beşinci soruya verdikleri yanıtlar Memnuniyet ve Memnuniyetsizlik olmak üzere iki tema altında toplanmıştır. Görüşmeye katılan 21 öğrenci, öğretmenin ders işleme şeklinden memnun olduklarını ifade etmişlerdir. Öğrenciler, öğretmenin kişilik özelliklerine ilişkin olarak öğretmenin esprili, neşeli ve çok sert olmamasından memnun olduklarını dile getirmiştir. Bir öğrenci ise öğretmenin disiplinli olmasından memnun olduğunu ifade etmiştir. Öğrencilerin bu yöndeki ifadelerine ilişkin örnekler aşağıda verilmiştir.

"Matematik dersini düzgün işlerdi. Fakat öğrencilerden dolayı dinleyemezdik. Öğretmen normal ders işliyor, anlamayan olursa tekrar anlatırdı. Memnundum, ders ĕglenceliydi. Bazen espri yapıyordu. Öğrencileri derste tutmak için ara sıra böyle yapmalı (Ö22)"

Görüşmeye katılan öğrenciler, 7.sınıf matematik dersi öğretmenlerinin ders anlatma şeklinden memnuniyetlerinin sebeplerini şu şekilde ifade etmişlerdir: dersin eğlenceli geçmesi, çok soru tipi ile karşılaşılması, konuların üzerinde yeterince durulup pekiştirilmesi, öğretmenin ödül verip öğrencileri teşvik etmesi, anlamadıkları yeri öğretmenin yeniden anlatması, derste kendilerinin aktif olması ve dersin soru üzerinden 
işlenmesi, öğretmenin seviyelerine inebilmesi ve öğretmenin sevilmesi. Öğrencilerin bu yöndeki ifadelerine ilişkin örnekler aşağıda verilmiştir.

"Öğretmenim gerçekten çok iyi anlatıyordu. Seviyemize inerek anlatıyordu. Bizi

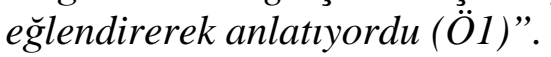

"Çok güler yüzlü davranırdı çok ilgilenirdi bizimle. Sürekli bizi tahtaya kaldırdı. Artılar verirdi. Memnundum çünkü bize ilgi göstermesi özellikle güler yüzlü olması çok güzeldi(Ö27)”.

"Yedinci sınıf öğretmenimi zaten çok seviyordum. Bence dersin öğretmeni çok önemli. Mesela ben bir dersin öğretmenini seversem dersi de seviyordum. Yedinci sinıftaki öğretmenimiz daha neşeliydi, dersi daha ĕ̆lenceli anlatıyordu. Komiklikler yapıyordu. Bence bu çok önemli çünkü hocayı dinlemek istiyordum. Öğretmen çok katı olmamal,, insanı kendinden soğutmamall, o zaman dersi dinlemek istemiyorum(Ö3)".

Görüşmeye katılan 9 öğrenci ise öğretmenlerinin ders işleme şeklinden memnun olmadıklarını ifade etmişlerdir. Öğrenciler konuların üzerinde çok durulmaması, dersin sıkıcı geçmesi, dersin çok hızlı işlenmesi, öğretmenin öğrencileri susturamaması, belirli sayıda öğrenci ile ders işlemesi, soruları çözemediklerinde öğretmenin kızması gibi nedenlerle öğretmenlerinin ders işleme şeklinden memnun olmadıklarını dile getirmişlerdir. Bu ifadelere yönelik örnek cümleler aşağıda verilmiştir.

"Yedinci sınıfta hoca soruları tahtaya yazar, ilk önce kendisi tahtaya sorular çözer, sonra öğrencileri tahtaya kaldırdı. Çok memnun değildim. Sadece birkaç öğrenci kaldırıldı, diğger ögrenciler de isteksiz olduğu için çok sıkıcı geçiyordu (Ö18)”.

"Çok hızlı anlatıyordu anlamak zorlaşlyordu. O yüzden bu ders işleme şeklinden memnun değildim. Biz birinci soruyu yazarken o ikinci soruyu çözüyordu. O nedenle yetişemiyorduk (Ö19)”.

Öğrencilere öğrenme-öğretme süreci ile ilgili bilgi edinmek amacıyla öğrenci görüşme formunun beşinci sorusu olan "Öğretmeniniz ders işlerken farklı araç gereçler kullanır mıydı?" sorusu yöneltilmiştir. Görüşmeye katılan öğrencilerden 17 tanesi öğretmenlerin ders işlerken cetvel, pergel, açıölçer dışında farklı bir araç gereç kullanmadıklarını belirtmişlerdir. Bu ifadelere yönelik örnek cümleler aşağıda verilmiştir.

"Cetvel kullanıyorduk. Bir tek onun dışında bir şey kullanmıyorduk. Matematik setimiz vardı. Ama ögretmenimiz sadece cetvel kullanıyordu (Ö9)”.

Görüşmeye katılan öğrencilerden 13 tanesi ise öğretmenlerinin ders işlerken, çoğunlukla geometri konularında farklı araç-gereç kullandıklarını ifade etmişlerdir. $\mathrm{Bu}$ araçgereçlerin projeksiyon, üç boyutlu geometrik şekiller ve simetri aynası olduğunu belirtmişlerdir. Bir öğrenci de öğretmenin kendisinin ders esnasında kâğıtları parçalayarak oluşturduğu geometrik şekillerle dersi görselleştirdiğini ifade etmişlerdir. Ders işlerken öğretmenlerinin farklı araç-gereç kullandığını belirten öğrenciler bu durumun öğrenmelerini olumlu yönde etkilediğini ve öğrenmede kalıcılığı arttırdığını belirtmişlerdir

"Farklı araç-gereçleri kullanıyorduk. Çok sık kullanmasak ta kullanıyorduk. Bu farklı 
araçları kullanmak görsel hafıza açısından çok önemli. Sinavlarda çok işime yarıyor. Defterimize yazdıklarımı aklıma gelmediği zaman o görüntüyü hatırlıyorum. Projeksiyon kullanıyorduk. Slayt hazırlıyordu öğretmenimiz birkaç tane internet sitesine gidiyorduk ya da slaytla kitabımızı açıyorduk, oradan takip ediyorduk (Ö10)”.

"Cetvel, gönye kullantyordu. Eşlik ve benzerlik konusunda küp falan getirmişti. Yansımada simetri aynası getirdi. Araç-gerecin faydası oluyor motive ediyor bizi. Öğrenmemizi iyi etkiliyor. Sınav esnasında yaptığımız şeyleri hatırlıyorduk, daha iyi oluyordu (Ö16)".

Görüşme formunun altıncı sorusu olan "Matematik dersinde etkinlik yapar mıdınız? Yapılan bu etkinliklerin sizlere ne gibi faydası oldu?" sorusu yöneltilmiştir. Görüşmeye katılan öğrencilerden 18 tanesi öğretmenlerinin matematik dersinde farklı bir etkinlik yapmadıklarını, klasik ders işlediklerini öğretmenlerinin test dağıtarak bol bol soru çözdüklerini ifade etmişlerdir. Öğrencilerden bir tanesi ise öğretmenin etkinlik yapmadığını ve bu durumdan memnun olduğunu ifade etmiştir. Bu öğrencilerden iki tanesi de ders işlerken etkinlik yapmadıklarını, ders kitabındaki etkinliklerin ev ödevi olarak verildiğini ifade etmişlerdir.

"Etkinlik yapmazdık. Örnekler çözerdik. Bunların bize etkisi oldu. Çünkü soru tiplerini gördük (Ö1)”.

"Hayır yapmazdık. Hocamı deftere sorular yazdırır ve onları çözdürüyordu. Açıkçası ben de etkinliklerin bir işe yaramadığını düşünüyorum (Ö30)”.

Görüşmeye katılan 12 öğrenci, matematik dersinde öğretmenlerin farklı etkinlikler yaptırdıklarını belirtmiştir. Bu öğrencilerden 4 tanesi etkinliklerin dersi eğlenceli hale getirdiğini, 2 tanesi etkinliklerle öğrendiklerinin daha kalıcı olduğunu birer öğrencide etkinliklerin konuları daha iyi anlamalarını sağladığını, öğrencilerin derse katılımlarını ve motivasyonlarını arttırdıklarını belirtmiştir. Bir öğrenci ise ders kitabındaki etkinlikleri yaptıklarını ve bu etkinliklerin faydası olmadığını ifade etmişlerdir.

"Evet, kitabınızda etkinlikler vardı. Onların hepsini yapardık. İşte yani görsel hafiza çok önemli benim için. Ögrenmede çok yardımcı oluyor. Hem de ĕ̆lenceli oluyor (Ö10)”.

"Matematik dersinde etkinlik yapıyorduk. Ders kitabımızdaki etkinlik kısımlarında malzemeleri getirip yapardık. Bir şey uyguladıktan sonra onu bir daha unutmuyorsun $(\ddot{O} 11)$.

"Evet, ders kitabındaki etkinlikleri yapıyorduk. Çok fazla bir katkısı olmadı. O kadar ayrıntıya girmiyorlar. Etkinliklerle ilgili sorular çıkmıyor (Ö12)”.

Matematik eğitimindeki öğrenme güçlüklerinin en aza indirgenebilmesi için çözüm önerileri elde etmek amaciyla öğrencilere görüşme formunun 7.sorusu olan "Sence matematik dersi nasıl işlenilseydi öğrenciler zorlandıkları konuları daha iyi anlardı ?" sorusu sorulmuştur. Bu soruya ilişkin yanıtlar Tablo 5'te görülmektedir. 
Tablo 5. Öğrenci görüşme formu yedinci soru kategori tablosu.

\begin{tabular}{ll}
\hline $\begin{array}{l}\text { SORU 7: Sence matematik dersi nasıl işlenilseydi } \\
\text { öğrenciler zorlandıkları konuları daha iyi anlardı? }\end{array}$ & \\
& \\
\hline Öneriler & ifade eden öğrenciler \\
\hline Eğitim Öğretim Sürecine Yönelik & Ö1,Ö4,Ö6,Ö15,Ö19,Ö20,Ö21,Ö22,Ö24,Ö29 \\
\hline Dersin eğlenceli hale getirilmesi & Ö13,Ö15,Ö18,Ö19,Ö20,Ö30 \\
Derslerin görselleştirilmesi (Araç-gereç kullanımı ) & Ö8,Ö11,Ö22,Ö24 \\
Derste öğrencilerin aktif olması & Ö6,Ö16,Ö21 \\
Derslerde oyun ve yarışma düzenlenmesi & Ö21 \\
Öğrencilerin ödüllendirilmesi & \\
\hline Öğretmene Yönelik & Ö5,Ö24,Ö23,Ö27 \\
\hline Derslerde çok soru çözülmesi & Ö1,Ö11,Ö27 \\
Öğrencilerin öğretmenden çekinmeden anlayamadıkları & Ö6,Ö12,Ö27 \\
konuları sorabileceği bir ders ortamı oluşturulması & Ö3,Ö9 \\
Konu anlatımına ağırlık verilmesi & Ö9,Ö23 \\
İyi anlatan bir öğretmen olması & \\
Öğretmenin kendisini sevdirmesi & Ö2,Ö10,Ö16 \\
\hline Yapılabilecek Yeni Düzenlemeler & Ö7,Ö21,Ö25 \\
\hline Öğrencilere bire bir eğitim verilmesi & Ö13,Ö17 \\
Konular basitleştirilmesi & Ö16 \\
Okulda özel kurslar verilmesi & Ö13 \\
Matematik sınıflarında ders işlenmesi & \\
Özel matematik okullarının açılması & \\
\hline
\end{tabular}

Görüşmeye katılan öğrencilerin yedinci soruya ilişkin verdiği yanttlardan elde edilen öneriler Ĕ̆itim öğretim sürecine yönelik, Ö̈̆retmene yönelik ve Yapılabilecek yeni düzenlemeler olmak üzere 3 tema altında toplanmıştır.

Öğrenciler ĕgitim-öğretim sürecine yönelik dersin eğlenceli hale getirilmesi, derslerin görselleştirilmesi (araç-gereç kullanımı), derste öğrencilerin aktif olması, derslerde oyun ve yarışma düzenlenmesi ve öğrencilerin ödüllendirilmesi önerilerinde bulunmuşlardır.

Görüşmeye katılan 10 öğrenci matematik dersinin eğlenceli bir şekilde işlenmesi durumunda öğrencilerin matematik dersindeki konuları daha iyi anlayacağını ifade etmişlerdir.

"Klasik anlatımdan daha çok kendiniz yapsaydık. Çok soru çözelim tamam. Ama daha renklenseydi, ders ortamını daha da güzelleştirseydik, eğlenceli olsaydı daha da severdik. Öğrencilerin kendi aralarında iletişim kurmaları sağlansaydı. Materyal getirilseydi. Daha iyi anlaşılırdı (Ö19)”.

"Araç-gereç getirerek dersi işleselerdi. Dersi görsel hale getirdiklerin de daha aklınızda kalırdı. Daha iyi işlenebilirdi (Ö18)”.

"Bence öğrenciler derste daha fazla aktif olurlarsa daha iyi anlayabilirler. Daha eğlenceli hale getirmeye çalışırdım. Çoğu öğrenciye matematik sıkıcı bir ders olarak geliyor. Ders eğlenceli hale getirilseydi, ilgi çekebilir (Ö24)”.

Görüşmeye katılan öğrenciler öğretmene yönelik teması altında, ihtiyaç duydukları konularda çok soru çözülmesi, öğrencilerin öğretmenden çekinmeden anlayamadıkları konuları sorabileceği bir ders ortamı oluşturulması, konu anlatımına ağırlık verilmesi, öğretmenin kendisini sevdirmesi, iyi anlatan bir öğretmen olması önerilerinde bulunmuşlardır. Öğrencilerin bu yöndeki ifadelerine ilişkin örnekler aşağıda verilmiştir. 
"Bence bir kere matematik öğretmeni sevimli ve iyi birisi olması lazım. Çünkü kötü ögrretmen olunca, yani öğretmeni sevmeyince ben dersi de sevmiyorum. Matematik dersinin ögrretmeni daha önemli. Çünkü hiç bilmediğimiz şeyleri anlatıyor. Türkçe ve Sosyal bilgiler dersinde bir kulak dolgunluğu var. Günlük hayattan bazı şeyleri biliyoruz. Matematik öğretmeninin gıcık olmaması lazım. O çok büyük bir etken. Ö̆gretmenin nasıl anlattı̆̆ da önemli. Akıcı bir şekilde anlatmalı (Ö9)”.

Öğrenciler yapılabilecek yeni düzenleneler teması altında konuların basitleştirilmesi, öğrencilere bire bir eğitim verilmesi, okulda özel kurslar verilmesi, matematik sınıflarında ders işlenmesi, özel matematik okullarının açılması gibi önerilerde bulunmuşlardır. Öğrencilerin bu yöndeki ifadelerine ilişkin örnekler aşağıda verilmiştir.

"Ders daha basite indirgenebilir ya da günlük hayattan örnekler verilerek anlatılabilirdi (Ö7)”.

"Birebir mesela çalıştırllsaydı. Mesela geçen sene derslik sistemi vardı. Matematik sınıfımız vardı. Her yerde matematik materyalleri vard. Onlar ilgimizi çekiyordu. Bahçede falan ders işleyebilirdik, farklılık yapılabilirdi. Matematik ile ilgili mesela oyun oynayabilirdik. Mesela Ingilizce dersinde yapıyoruz bazen (Ö16)”.

\section{Sonuçlar ve tartıșma}

$\mathrm{Bu}$ çalışmanın amacı, 7.sınıf matematik dersinde (2005) öğrencilerin zorlandıkları konuları belirlemek, öğrencilerle yapılan görüşmelerle belirlenen zorlukların altında yatan nedenleri ortaya çıkarmak ve bu zorlukların giderilmesine yönelik çözüm önerileri sunmaktır.

Tablo 6. Öğrencilere uygulanan anket ve görüşme sonuçlarına göre zorlanılan konuların karşılaştırılması.

\begin{tabular}{|l|l|}
\hline \multicolumn{1}{|c|}{ Anket sonuçlarına Göre Zorlanılan Konular } & Öğrenci Görüşmelerine Göre Zorlanılan Konular \\
\hline Faiz hesaplamaları & \\
Denklem problemleri & Faiz hesaplamaları \\
Denklemler & Yüzde hesaplamaları \\
Dik dairesel silindirin hacmi & Permütasyon \\
Yüzde hesaplamaları & Denklemler \\
Dik dairesel silindirin alanı & Dik dairesel silindirin hacmi \\
Rasyonel sayılarla çok adımlı işlemler & Cebirsel ifadeler \\
Permütasyon & Dik dairesel silindirin alanı \\
Cebirsel ifadeler & Oran ve orantı \\
Rasyonel sayılarla ilgili problemler & Doğrusal denklemlerin grafikleri \\
Çember veya dairede açılar & Koordinat sistemi \\
Doğrusal denklemlerin grafikleri & Çember veya dairede açılar \\
Birim küplerle oluşturulan yapıları izometrik kağıda & Çokgenler \\
çizme & Denklem problemleri \\
Daire ve daire diliminin alanları & Merkezi eğilim ve yayılım ölçüleri \\
Çember ve çember parçasının uzunluğu & Birim küplerle oluşturulan yappları izometrik kağıda \\
\hline
\end{tabular}

Anket ve görüşme sonuçlarına baktığımızda zor olarak algılanan ilk 15 konu karşılaştırıldığında 11 konunun ortak olduğu ve büyük oranda örtüştügü görülmektedir. 
Durmuş, ilköğretim matematik derslerinde zor olarak algılanan konuları belirlemek ve bu zorlukların arkasında yatan nedenleri ortaya çıkarmak amacıyla yaptığı çalışmada ilköğretim matematik müfredatındaki tüm konuların, likert tipi bir anketle zorluk indeksini tespit etmiștir. Durmuş'un yaptığı çalışmada zorluk indeksi $\% 15$ ve üzeri olan konular belirlenmiştir [23]. Durmuş'un çalışmasındaki bu konular ile bizim çalışmamızdaki zor olarak algılanan konular karşılaştırılmıştır. Buna göre "dairenin ve daire diliminin alanı", "dik dairesel silindirin alanı ve hacmi” konuları her iki çalışmada da zorlanılan konular arasında yer almaktadır. Durmuş'un çalışmasında öğrencilerle yapılan görüşmelerde öğrenciler “Özellikle bilinmeyenlerin kullanıldığı konuları anlamak daha zor" demişlerdir [23]. Bu çalışmaya göre ise öğrencilerin özellikle cebir öğrenme alanında zorlandıkları ortaya çıkmıştır. Dolayısıyla iki çalışmanın sonuçları birbirini desteklemektedir.

Evirgen, ilköğretim 6.sınıf matematik müfredatında yer alan kazanımların, öğrenci ve öğretmenlere göre zorluk dereceleri araştırmıştır [28]. Bu çalışmada, en çok zorlanılan kazanımların; "dikdörtgenler prizması", "kare prizma ve küpün hacmine ait bağıntıları oluşturmak", "eş küplerle oluşturulmuş yapıların farklı yönlerden görünümlerini çizmek" ve "birinci dereceden bir bilinmeyenli denklemleri çözmek" olduğu sonucuna ulaşmıştır. Evirgen'in çalışmasında yer alan kazanımlar ile bu çalışmanın öğrencilere göre zor olarak algılanan konuların içinde yer alan "denklemler", “denklem problemleri", "silindirin alan ve hacmi" ve "birim küplerle oluşturulan yapıları izometrik kağıda çizme konuları" ile paralellik göstermektedir. Sonuç olarak, 6.sınıfta zorlanılan kazanımların devamı olan ya da ortak öğrenme alanına ait olan konularda 7.sınıfta da zorlanıldığı söylenilebilir.

2013 yılında Milli Eğitim Bakanlığı ortaokul (5.,6.,7. ve 8.sınıflar) matematik öğretim programını sadeleştirerek güncelledi ve 5.sınıftan başlanarak kademeli olarak yeni programa geçiş yapıldı. 2005 ve 2013 yedinci sınıf matematik öğretim programları karşılaştırılmış ve incelenmiştir. Araştırma sonucunda öğrencilere göre zor olarak algılanan konular içerisinde yer alan bazı konular 2013 öğretim programından çıkarılmış veya başka bir sınıfa alınmıştır. Bu konular ve değişiklikler Tablo 7'de verilmiştir.

Tablo 7. 2013 programında en çok zorlanılan konularda yapılan değişiklikler.

\begin{tabular}{|l|l|}
\hline Bu Çalışmaya Göre En Çok Zorlanılan Konular & $\mathbf{2 0 1 3}$ Programındaki Değişiklikler \\
\hline Faiz hesaplamaları & $\begin{array}{l}\text { Faiz hesaplamaları ile ilgili kazanım çıkartılarak yüzde } \\
\text { hesaplamaları kazanımını altında yer verilmiş ve } \\
\text { basit (bileşik olmayan) faiz problemleri olarak ifade } \\
\text { edilmiştir. Formül vermeyi gerektirmeyen faiz } \\
\text { problemleriyle sınırı kalınmıştır. }\end{array}$ \\
\hline Cebirsel ifadelerle çarpma & 8.sınıfa alındı. \\
\hline Dik dairesel silindirin alanı & 8. sınıfa alındı \\
\hline Dik dairesel silindirin hacmi & 8.sınıfa alındı \\
\hline Permütasyon & Programdan tamamen çıkarıldı \\
\hline
\end{tabular}

Tablo 7 incelendiğinde bu çalışmanın sonuçlarının desteklediği değişiklikler, matematik programında yerini almıştır. $\mathrm{Bu}$ araştırmadaki zorlanılan konuların bir kısmının 2013 programında yer almadığı ve programın bu doğrultuda hafifletildiği söylenebilir. 2013 programında, Tablo 7'deki konuların dişında daha birçok değişiklik yapılmıştır. Ayrıca 2017 yılında matematik öğretim programı tekrar yenilenerek, güncellenmiştir. 2013 yılı matematik programı 7. sınıfta yer alan "doğrusal denklemler" öğrenme alanına ait 3 
kazanım, 2017 yılı matematik programında 8. sınıfa alınmıştır. "Doğrusal denklemlerin grafikleri” öğrencilerin zor olarak algıladığı konular arasında yer aldığı için, bu çalışmanın desteklediği bir değişiklik olarak karşımıza çıkmaktadır.

Araştırmadan elde edilen nitel verilere ilişkin sonuçlar incelendiğinde, öğrencilere göre konuların zor olarak algılanmasının başlıca nedenlerini; matematik dersinin sevilmemesi, ders öğretmeninin olumsuz özellikleri, konuların çok olması, konuları pekiştirmede zaman problemi yaşanması, matematik korkusu, konuların birbiri ile ilişkili olması ve öğrencilerin yeterince çalışmaması olarak ifade edilmiştir. Konuların birikimli olarak ilerlemesinden dolayı, özellikle öğrencilerin hazır bulunuşluk düzeyleri ölçülmeli varsa eksiklikleri mutlaka giderilmelidir.

Aksu'nun çalışması da göre de, hazır bulunuşluk seviyelerinin tespit edilmesi, öğrencilerin başarısı ve kavram yanılgılarının tespit edilmesi açısından faydalı olacaktır. Bu sebeple konuların öncesinde ve sonrasında öğrencilerin konu hakkındaki bilgilerini ölçmek amacıyla tanı koyucu testler, yanılgılarını tespit etmek veya bildiklerini değerlendirmek amaciyla kavram haritaları, öz değerlendirme formları gibi alternatif değerlendirme araçları kullanılmalıdır. Bu durum öğretmenin öğrencilerinin bir sonraki konuya ne kadar hazır olduğunu bilmesini ve varsa yanılgılarını gidermesine yönelik tedbirler almasını kolaylaştıracaktır [29].

Ülkemizdeki pek çok öğrenci matematiğin zor olduğunu ve matematiği başaramayacağını düşünerek kaygılanmakta ve matematiğe karşı olumsuz tutum geliştirmektedir. Bu durum ilköğretimden başlamakta okul yılları ilerledikçe maalesef artarak devam etmektedir. Daha da kötüsü; kendilerini matematiği öğrenecek kadar zeki olmadıkları, matematiğin onların uğraşacağı konular arasında bulunmadığı kanaatine varmaktadırlar. Bu durumda öğretimin ve öğretmenin yaklaşımının önemli rolü vardır [30]. Bu çalışmada, yapılan görüşmelerde öğrenciler, konuların öğrenilmesinde öğretmenin büyük bir rolünün olduğunu ifade etmişlerdir. Öğrencilere göre, öğretmenin dersi eğlenceli hale getirmesi, görselleştirmesi, öğrenciyi aktif hale getirmesi, öğrencinin seviyesine inebilmesi, konuların üzerinde yeterince durarak konuları pekiştirmesi öğrenci başarısını olumlu etkilemektedir.

$\mathrm{Bu}$ araştırmanın sonucunda, öğrencilerin özellikle cebir ve ölçme öğrenme alanlarında daha çok zorlandıkları belirlenmiştir. Bu konuların öğretiminde öğrencilerde anlamlı öğrenmenin gerçekleşmesi için konular günlük yaşamla ilişkilendirilmeli, somut materyaller kullanılarak, öğrencilerin aktif katılımının sağlandığı ve öğrencinin derse isteğini arttıran etkinliklerin olduğu öğretim ortamları oluşturulmalıdır.

$\mathrm{Bu}$ araştırma 2005 yılı öğretim programına göre eğitim almış öğrencilerle yürütülmüştür. Yedinci sınıf matematik öğretim programında konuların fazla olduğu sonucuna ulaşılmıştır. 2013 ve 2017 matematik öğretim programlarına bakıldığında ise araştırmanın sonuçlarının desteklediği birçok değişiklik yapıldığı görülmüştür. Program büyük ölçüde hafifletilmiştir. Bu durumda öğrencilerin matematik öğretim programında yer alan konuları daha rahat öğrenebileceği söylenebilir. Başka bir araștırmada 2017 yılı matematik öğretim programında zor olarak algılanan konular ve nedenleri araştırılabilir. 


\section{Kaynaklar}

[1] Umay, A., Matematiksel muhakeme yeteneği. Hacettepe Üniversitesi Eğitim Fakültesi Dergisi, 24, 234-243, (2003).

[2] MEB, İlköğretim matematik 6-8. sınıflar öğretim programı kitabı, Talim ve Terbiye Kurulu Başkanlığı, Ankara, (2005).

[3] Küçükahmet, L., Konu alanı ders kitabı incelemesi, Ankara: Nobel Yayın Dağıtım, (2004).

[4] Sarıer, Y., Altıncı sınıf matematik öğretmenlerinin matematik dersi öğretim programına ilişkin görüşleri. Yüksek Lisans Tezi, Eskişehir Osmangazi Üniversitesi, Sosyal Bilimler Enstitüsü, Eskişehir, (2007).

[5] Demirel, Ö., Kuramdan uygulamaya eğitimde program geliştirme, Ankara: Pegem A Yayıncilık, (1999).

[6] Olkun, S., İlköğretimde etkili matematik öğretimi için ipuçları, İlköğretmen Dergisi, 5, 31-35, (2007).

[7] Evirgen, O., İlköğretim 7. sınıf matematik öğretim programında zor olarak algılanan konular ve öğretmen, öğrenci görüşleri. Yüksek Lisans Tezi, Balıkesir Üniversitesi, Fen Bilimleri Enstitüsü, Balıkesir, (2014).

[8] Gürbüz, R., Toprak, Z., Yapıcı, H. ve Doğan, S., Ortaöğretim matematik müfredatında zor olarak algilanan konular ve bunların nedenleri, Gaziantep Üniversitesi Sosyal Bilimler Dergisi, 10 (4), 1311-1323, (2011).

[9] Tall, D. ve Razali, M.R., Diagnosing students' difficulties in learning mathematics, Journal of Mathematical Education in Science and Technology, 24(2), 209-222, (1993).

[10] Ersoy, Y. ve Ardahan, H., İlköğretim okullarında kesirlerin öğretimi-II: tanıya yönelik etkinlikler düzenleme, www.matder.org.tr, (2003).

[11] Yetkin, E., Student difficulties in learning elementary mathematics, ERIC Digest. Clearing house for science mathematics and environmental education, (2003).

[12] Rasmussen, C. L., Reform in differential equations: a case study of students' understandings and difficulties, The Annual Meeting of American Educational Research Association, San Diego, CA, 13-17 April, (1998).

[13] Altun, M., Matematik öğretimi, Bursa: Alfa Yayın, (1998).

[14] Baker, J. D., Students' difficulties with proof by mathematical induction, The Annual Meeting of American Educational Research Association, New York, (1996).

[15] Aydın, N., Liselerde matematik derslerinde zor öğrenilen konular, zor öğrenilme nedenleri ve bunları öğretme yöntemleri, VIII. Eğitim Bilimleri Kongresi Bildiriler Kitabı, Cilt 1, Trabzon, 62-67, (1998).

[16] Zachariades, T., Christou, C., and Papageorgiou, E., The difficulties and reasoning of undergraduate mathematics students in the identification of functions, Proceedings in the 10th ICME Conference, Crete, Greece, (2002).

[17] Durmuş, S., Matematikte öğrenme güçlüklerinin saptanması üzerine bir çalışma, Kastamonu Eğitim Dergisi, 12(1), 125-128, (2004).

[18] Dikici, R. ve İşleyen, T., Bağıntı ve fonksiyon konusundaki öğrenme güçlüklerinin bazı değişkenler açısından incelenmesi, Kastamonu Eğitim Dergisi, 12(1), 105-116, (2004).

[19] Yenilmez, K., Çimen, E.E., On birinci sınıf matematik öğretim programında zorluk çekilen konular ve olası nedenleri, X. Ulusal Fen Bilimleri ve Matematik Ĕgitimi Kongres, Niğde, (2012). 
[20] Tatar, E., Okur M. ve Tuna A., Ortaöğretim matematiğinde öğrenme güçlüklerinin saptanmasına yönelik bir çalışma, Kastamonu Eğitim Dergisi, 16(2), 507-516, (2008).

[21] Kutluca T. ve Baki A., 10. sınıf matematik dersinde zorlanılan konular hakkında öğrencilerin, öğretmen adaylarının ve öğretmenlerin görüşlerinin incelenmesi, Kastamonu Eğitim Dergisi, 17(2), 609-624, (2009).

[22] Baki, A. ve Kutluca T., Dokuzuncu sınıf matematik öğretim programında zorluk çekilen konuların belirlenmesi, e-Journal of New World Sciences Academy, 4(2), 604-619, (2009).

[23] Durmuş, S., İlköğretim matematiğinde öğrenme zorluklarının saptanması ve zorlukların gerisinde yatan nedenler üzerine bir çalıșma, VI. Ulusal Fen Bilimleri ve Matematik Eğitimi Kongresi, Marmara Üniversitesi, İstanbul, (2004).

[24] Leech, N.L. ve Onwuegbuzi, A.J., A typology of mixed methods research designs, Qual Quant, 43(2), 265-275, (2007).

[25] Karasar, N., Bilimsel araştırma yöntemleri, Ankara : Nobel Yayınları, (2005).

[26] Yıldırım A. ve Şimşek H., Nitel araştırma yöntemleri, Ankara: Seçkin Yayıncilık, (2003).

[27] Johnstone, A.H. ve Mahmoud, N.A., Isolating topics of high perceived difficulty in school biology, Journal of Biological Education, 14(2), 163-166, (1980).

[28] Evirgen, R., İlköğretim altıncı sınıf matematik müfredatındaki kazanımların öğrenci ve öğretmenlere göre zorluk derecelerinin değerlendirilmesi, Yüksek Lisans Tezi, Necmettin Erbakan Üniversitesi, Eğitim Bilimleri Enstitüsü, Konya, (2013).

[29] Aksu, B., Fen ve teknoloji öğretim programında zor olarak algılanan konular ve olası nedenleri: öğretmen ve ögrenci görüşleri, Yüksek Lisans Tezi, Abant İzzet Baysal Üniversitesi, Eğitim Bilimleri Enstitüsü, Bolu, (2011).

[30] Baykul, Y., İlköğretim matematik öğretimi (1-5. Sınıflar), Ankara: Anı Yayıncılık, (1999). 